\title{
Correction: Massive right hemothorax as the source of hemorrhagic shock after laparoscopic cholecystectomy - case report of a rare intraoperative complication
}

Cristian Rapicetta ${ }^{1 *}$, Massimiliano Paci ${ }^{1}$, Tommaso Ricchetti ${ }^{1}$, Sara Tenconi ${ }^{1}$, Federico Biolchini ${ }^{2}$, Emilio Belluzzi ${ }^{2}$ and Giorgio Sgarbi ${ }^{1}$

\section{Correction}

After publication of this work [1], it was noticed that first and second names of co-authors of the article were reported in the wrong order with the exception of the corresponding author. The correct author list is listed in this article.

\section{Competing interests}

The authors declare that they have no competing interests.

\section{Author details}

${ }^{1}$ Thoracic Surgery Unit, Arcispedale Santa Maria Nuova, Viale Risorgimento 80, 42100 - Reggio nell'Emilia, Italy. ${ }^{2}$ Division of General Surgery, Magati Hospital, Via Martiri della Libertà 6, 42019 - Scandiano (Reggio nell'Emilia), Italy.

Received: 24 May 2013 Accepted: 24 May 2013

Published: 5 June 2013

\section{Reference}

1. Cristian, et al: Massive right hemothorax as the source of hemorrhagic shock after laparoscopic cholecystectomy - case report of a rare intraoperative complication. Patient Safety in Surgery 2011, 5:12.

\section{doi:10.1186/1754-9493-7-20}

Cite this article as: Rapicetta et al:: Correction: Massive right hemothorax as the source of hemorrhagic shock after laparoscopic cholecystectomy case report of a rare intraoperative complication. Patient Safety in Surgery 2013 7:20

\footnotetext{
*Correspondence: cristian.rapicetta@asmn.re.it

${ }^{1}$ Thoracic Surgery Unit, Arcispedale Santa Maria Nuova, Viale Risorgimento 80, 42100 - Reggio nell'Emilia, Italy

Full list of author information is available at the end of the article
}

Submit your next manuscript to BioMed Central and take full advantage of:

- Convenient online submission

- Thorough peer review

- No space constraints or color figure charges

- Immediate publication on acceptance

- Inclusion in PubMed, CAS, Scopus and Google Scholar

- Research which is freely available for redistribution 